\title{
PEMBUATAN GARAM MENGGUNAKAN KOLAM KEDAP AIR BERUKURAN
} SAMA

\author{
Imam Santosa \\ Program Studi Teknik Kimia \\ Universitas Ahmad Dahlan, Jl. Dr. Soepomo, Janturan Yogyakarta \\ Imamsuad@yahoo.com
}

\begin{abstract}
ABSTRAK
Di Indonesia garam sebagian besar diperoleh dari Air Laut yang diuapkan, namun demikian persoalan garam merupakan persoalan nasional yang sampai kini tidak kunjung selesai permasalahannya. Disatu sisi kualitas garam nasional kurang memenuhi syarat sebagai garam industri karena kandungan NaCl-nya kurang 97\% disisi lain masih rendahnya kualitas kebersihan garam untuk dikonsumsi sebagai makanan. Untuk mendapatkan garam berkualitas baik maka dikembangkan pembuatan garam menggunakan kolam kedap air berukuran sama.

Air laut dari pantai goa cemara dianalisa kandungan ion makronya, dibandingkan dengan standar yang ada. Air laut ditampung dalam wadah taransparan yang lebar dan dalam, diamati penurunan ketinggian tiap hari, untuk menghitung laju penguapan harian. Setelah laju penguapan didapatkan dibuat skema tata letak terpal untuk memproduksi garam dari air laut. Skema ini dicoba dengan skala kecil menggunakan ember. Kemudian hasil garamnya dianalisa secara kualitatif.

Hasil analisa densitas air laut dari pantai goa cemara sebesar 1,025 gr/cc dengan kandungan padartan 4,131 gr/100 gr air laut. Secara kuantitatif produksi garamnya 80 \% dari laut umumnya karena cukup dekat dengan muara, namun kualitas garam yang dihasilkan lebih bagus karena kandungan sulfat yang kecil. Laju penguapan air laut rata-rata per hari adalah $0,5 \mathrm{~cm}$, pada kondisi cuaca yang cerah. Metoda kolam kedap air menjanjikan masa panen garam yang fleksibel, dapat diaplikasikan dengan baik dan menghasilkan garam dengan kualitas yang baik.
\end{abstract}

Kata kunci : air laut, garam, kolam berukuran sama.

\section{PENDAHULUAN}

Kebutuhan garam Indonesia per tahun sekitar 2.200.000 ton, 1.000 .000 ton untuk kebutuhan konsumsi dan 1.200.000 ton untuk kebutuhan industri. Kapasitas produksi nasional 1.000.000 ton pertahunnya dengan rincian produksi garam rakyat sebanyak 700.000 ton dan PT. Garam 300.000 ton. Penggaraman rakyat sampai saat ini menggunakan sistem kristalisasi total sehingga kualitasnya masih kurang. Pada umumnya kadar NaClnya kurang dari 90\% dan banyak mengandung pengotor. Luas lahan penggaraman rakyat $25.542 \mathrm{Ha}$ atau sekitar 83,31\% dari luas areal penggaraman nasional. Mengingat tidak seimbangnya antara peningkatan kebutuhan garam dengan potensi produksi maka yang menjadi permasalahan adalah bagaimana meningkat potensi produksi dan kualitas garam nasional.

Jenis garam dapat dibagi dalam kualitas baik sekali, baik dan sedang. Kualitas baik sekali jika mengandung kadar $\mathrm{NaCl}>95 \%$, baik kadar $\mathrm{NaCl} 90-95 \%$, dan sedang kadar $\mathrm{NaCl}$ antara 80-90\% tetapi yang diutamakan adalah yang kandungan garamnya di atas 95\%. Garam industri dengan kadar $\mathrm{NaCl}>95 \%$ yaitu sekitar 1.200 .000 ton sampai saat ini seluruhnya masih diimpor, hal ini dapat dihindari mengingat Indonesia sebagai negara kepulauan.

Penelitian ini menawarkan ide penggunaan kolam kedap air berukuran sama untuk proses pembuatan garam dari air laut. Dengan penggunaan kolam ini maka penurunan air proses yang meresap ke tanah dapat dihindari, perubahan konsentrasi pengkristalan garam dapat diatur sehingga kualitas dan potensi produksi garam dapat meningkat. Selaian itu penggunaan kolam ini dapat diaplikasikan pada pantai dengan lahan berpermealitas tinggi, seperti pantai berpasir.

Kontribusi penelitian berupa teknologi tepat guna model pembuatan garam dari air laut menggunakan kolam kedap air berukuran sama secara batch. 


\section{LANDASAN TEORI}

Pembuatan garam dari air laut terdiri dari proses pemekatan air laut dengan penguapan dan pengkristalan garam. Bila seluruh zat yang terkandung dalam air laut diendapkan/dikristalkan akan terdiri dari campuran bermacam-macam zat yang terkandung, tidak hanya Natrium Klorida yang terbentuk tetapi juga beberapa zat yang tidak diinginkan ikut terbawa (impurities). Proses kristalisasi yang demikian disebut kristalisasi total.

Jika kristalisasi/pengendapan zat tersebut diatur pada tempat yang berlainan secara berturut-turut maka dapat diusahakan terpisahnya komponen garam yang relatif lebih murni. Proses kristalisasi demikian disebut kristalisasi bertingkat. Kristalisasi garam Natrium Klorida yang kemurniannya tinggi terjadi pada kepekatan $25^{\circ}$ Be sehingga menjadi $29^{\circ} \mathrm{Be}$, sehingga pengotoran dalam garam yang dihasilkan dapat dihindari/dikurangi.

Ada dua macam konstruksi penggaraman yang dipakai di Indonesia :

A. Konstruksi tangga (getrapte).

Yaitu konstruksi yang terancang khusus dan teratur dimana suatu petak penggaraman merupakan suatu unit penggaraman yang komplit, terdiri dari peminihan-peminihan dan mejameja garam dengan konstruksi tangga, sehingga aliran air berjalan secara alamiah (gravitasi).
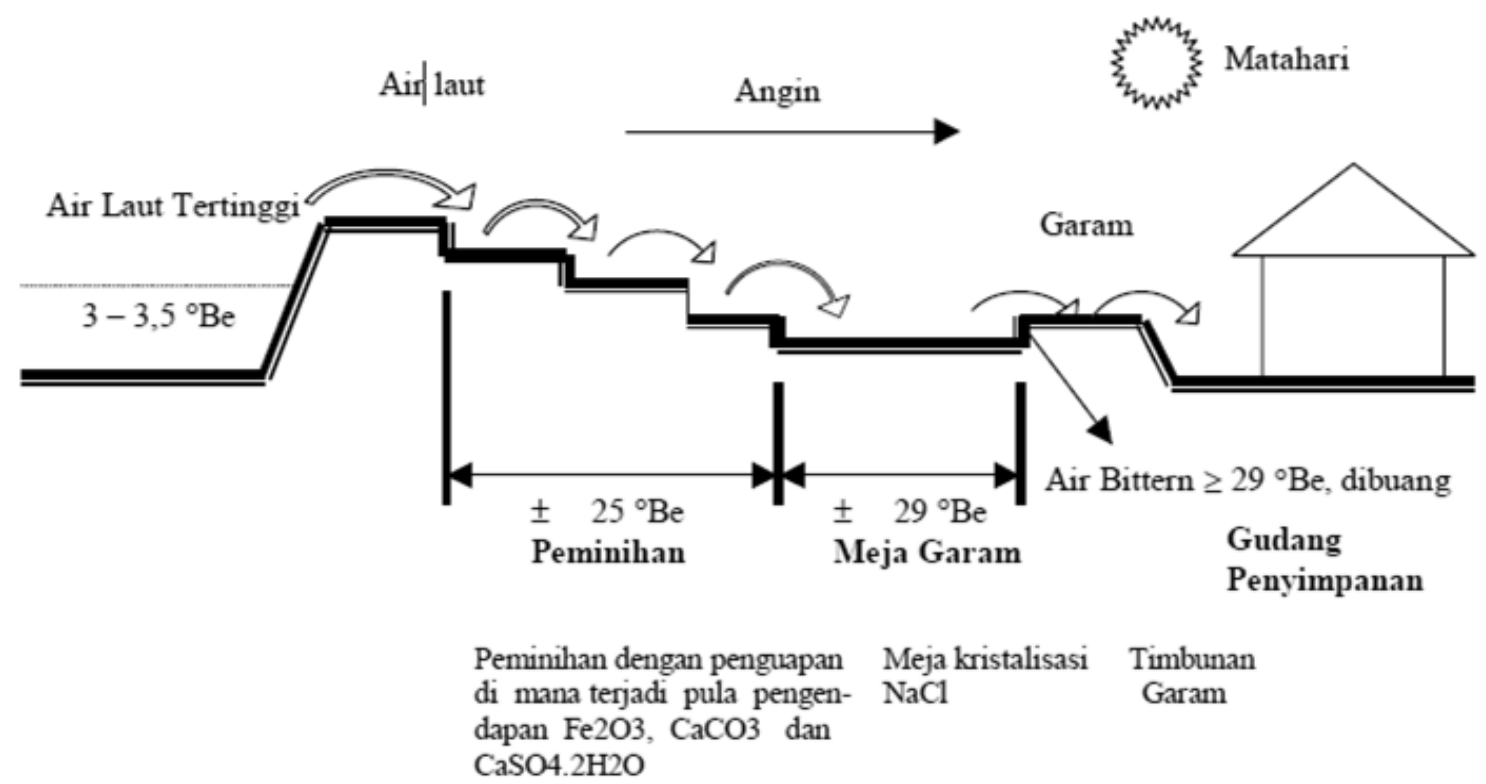

Gambar 1. Konstruksi tangga (getrapte)

B. Konstruksi komplek meja (tafel complex)

Yaitu konstruksi penggaraman dimana suatu kompleks (kelompok-kelompok) penggaraman yang luas yang letaknya tidak teratur (alamiah) dijadikan suatu kelompok peminihan secara kolektif, yang kemudian air pekat (air tua) yang dihasilkan dialirkan ke suatu meja untuk kristalisasi. 


\section{FLOW PROSES PEMBIKINAN GARAM PT. GARAM (Persero)}

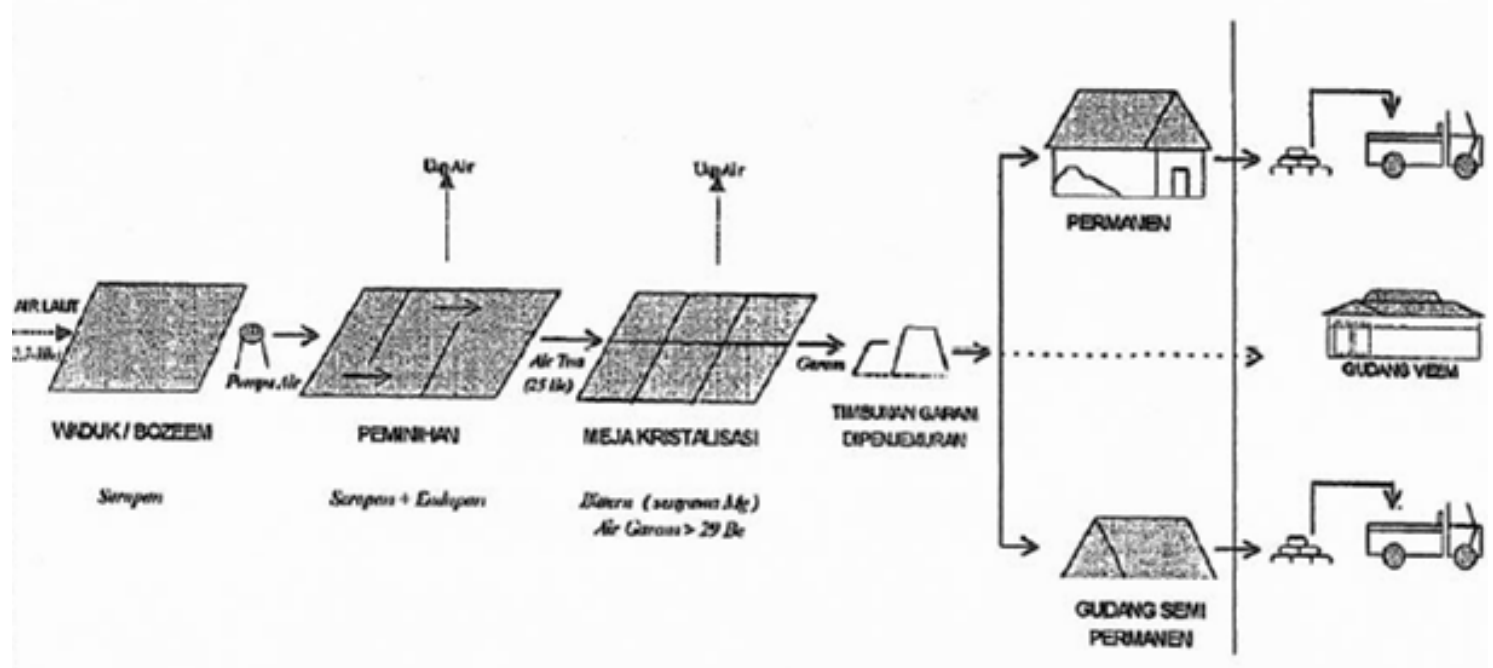

Gambar 2. Konstruksi komplek meja (tafel complex)

Pengaturan aliran dan tebal air dari peminihan satu ke berikutnya dalam kaitannya dengan faktor-faktor arah kecepatan angin dan kelembaban udara merupakan gabungan penguapan air (koefisien pemindahan massa). Kadar/kepekatan air tua yang masuk ke meja kristalisasi akan mempengaruhi mutu hasil. Pada kristalisasi garam konsentrasi air garam harus antara $25-29^{\circ}$ Be. Bila konsentrasi air tua belum mencapai $25^{\circ}$ Be maka gips (Kalsium Sulfat) akan banyak mengendap, bila konsentrasi air tua lebih dari $29^{\circ} \mathrm{Be}$ Magnesium akan banyak mengendap. Air Bittern adalah air sisa kristalisasi yang sudah banyak mengandung garamgaram magnesium (pahit). Air ini sebaiknya dibuang untuk mengurangi kadar Mg dalam hasil garam, meskipun masih dapat menghasilkan kristal $\mathrm{NaCl}$. Sebaiknya kristalisasi garam dimeja terjadi antara $25-29^{\circ} \mathrm{Be}$, sisa bittern $\geq 29^{\circ} \mathrm{Be}$ dibuang.

Pungutan garam di atas lantai garam, yang terbuat dari kristal garam yang dibuat sebelumnya selama 30 hari, berikut tiap 10 hari dipungut, disebut sistem portugis. Sedangkan pungutan garam yang dilakukan di atas lantai tanah, selama antara 10-15 hari garam diambil di atas dasar tanah disebut sistem maduris.

Pencucian garam bertujuan untuk meningkatkan kandungan $\mathrm{NaCl}$ dan mengurangi unsur Mg, Ca, SO4 dan kotoran lainnya. Air pencuci garam semakin bersih dari kotoran akan menghasilkan garam cucian lebih baik atau bersih. Persyaratan air pencuci yang digunakan biasanya air garam (Brine) dengan kepekatan $20-24^{\circ}$ Be dengan kandungan Mg kurang dari 10 g/liter.

Beberapa faktor yang menjadi variabel dalam produksi garam adalah :

1. Peningkatan kecepatan penguapan air laut.

Faktor yang paling menentukan terhadap kecepatan penguapan air laut adalah kecepatan angin dan radiasi matahari. Kecepatan angin berpengaruh karena angin membawa uap air dari permukaan air laut sedangkan radiasi berpengaruh karena merupakan sumber masukan energi yang menentukan berlangsungnya penguapan. Pemberian warna pada dasar tanah atau air laut dapat memperbesar radiasi netto dan suhu cairan. Demikian juga letak tanah akan memberikan pengaruh terhadap besarnya kecepatan angin yang diterima sehinga akan berpengaruh terhadap penguapannya. Upaya peningkatan kecepatan penguapan dengan 
menaikkan dua variabel diatas akan dapat meningkatkan produktifitas dari areal penggaraman.

2. Penurunan peresapan tanah.

Resapan air laut kedalam tanah, terutama pada bagian peminian yang merupakan areal terluas dari lahan pegaraman (sekitar 80-90\%) adalah faktor yang merugikan. Saat ini usaha pemadatan tanah lahan pegaraman hanya dilakukan pada meja-meja tempat kristalisasi (tempat pengendapan garam) sedang lahan peminihan sama sekali tak pernah dilakukan.

3. Pengaturan konsentrasi pengkristalan garam.

Air laut mengandung berbagai senyawa garam dan masing-masing mengendap berdasarkan tingkat kelarutannya, mulai senyawa besi (ferri oksida), calsium (gips), Sodium (garam dapur) dan Magesium (Magnesium klorida dan sulfat). Diantara senyawa-senyawa garam yang terkandung didalam air laut $\mathrm{NaCl}$ merupakan senyawa yang paling besar porsinya. Dengan cara mengatur pengendapannya berdasarkan sifat-sifat kelarutannya akan diperoleh hasil $\mathrm{NaCl}$ yang maksimal. Bersadarkan hasil percobaan yang dilakukan Usiglio, $\mathrm{NaCl}$ akan mengendap pada konsentrasi antara 25 sampai dengan $29{ }^{\circ} \mathrm{Be}$. Dengan cara mengatur pengen-dapan $\mathrm{NaCl}$ pada kisaran konsentrasi tersebut akan diperoleh endapan $\mathrm{NaCl}$ sebesar $70 \%$ dengan kemurnian $98 \%$.

4. Perbaikan cara pengolahan tanah.

Dalam produksi garam $\mathrm{NaCl}$ mengendap diatas permukaan tanah untuk itu kualitas visual garam yang diperoleh sangat ditentukan oleh kondisi tanah yang digunakan untuk pengendapan (kualitas meja kritalisasi). Kondisi tersebut sangat berpengaruh sekali terhadap kualitas produksi garam rakyat, sedangkan produksi cara PT. Garam hal tersebut dapat diatasi dengan cara pungutan garam diatas garam (karena sebelum pungutan periodik 10 harian terlebih dahulu dibuat landasan kristal garam yang berumur 30 hari). Untuk memperoleh kualitas tanah meja kristalisasi yang baik sebelum melakukan pelepasan air tua (air laut $25{ }^{\circ} \mathrm{Be}$ ) tanah tersebut terlebih dahulu diperlakukan Kesap dan Guluk ( biasanya dilakukan 3 kali untuk memperoleh kualitas kekerasan tanah yang memenuhi syarat). Kesap dilakukan dengan tujuan untuk membuang lumpur dan lumut yang menempel pada permukaan tanah sedangkan Guluk bertujuan untuk mengeraskan landasan permukaan tanah. Dengan pengolahan tanah meja kristalisasi yang baik sebagaimana cara diatas akan dapat meningkatkan kualitas garam yang diperoleh.

5. Penggunaan teknologi baru dalam produksi.

\section{METODE PENELITIAN}

Penelitian dilakukan secara eksperimental di laboratorium universitas Ahmad Dahlan, Yogyakarta. Sedang analisa kandungan ion makro dilakukan di BTKL yogyakarta. Bahan baku berupa air laut diambil dari pantai Goa Cemara. Alat penelitian antara lain berupa: peralatan gelas di laboratorium, alat-alat analisis kimia volumetris (buret, labu Erlenmeyer, piknometer dan lain-lain), neraca digital, desikator, oven. Adapun tahap-tahap penelitian :

1. Analisa densitas air laut menggunakan piknometer.

2. Analisa kandungan padatan air laut : Air laut 100 gram dimasukkan dalam cawan porselen, dipanaskan sampai semua air menguap sempurna.

3. Analisis kandungan ion makro di BTKL secara volumetris.

4. Menghitung laju penguapan air laut: Air laut ditampung dalam wadah transparan setinggi $10 \mathrm{~cm}$, diamati penurunannya tiap 24 jam selama 10 hari.

5. Pembuatan skema tambak garam dengan metoda kolam kedap air berukuran sama.

6. Analisa produk garam hasil pilot plant di BTKL.

\section{HASIL DAN PEMBAHASAN}

Hasil analisa densitas air laut dari goa cemara sebesar 1,025 gr/cc dengan kandungan padartan 4,131 gr/100 gr air laut. Sedang menurut Riley dan skirrow, 1975 densitas air laut adalah 1,0258 kg/L. Dari analisa kandungan ion makro di tabel 2 dan 3 dapat dinyatakan secara kualitatif air laut di pantai di goa cemara mengandung $\mathrm{Na}$ dan $\mathrm{Cl}$ lebih rendah 
dibanding analisa Riley dan Skirrow, sehingga secara dengan neraca masa dapat dihitung hasil garam per liter air lautnya hanya $80 \%$ dari seharusnya. Namun kandungan sulfat yang rendah memungkinkan kualitas garam yang dihasilkan dari air laut goa cemara lebih baik. Hal ini mungkin karena pantai goa cemara relatif dekat dengan muara sungai.

Tabel 1. Kandungan ion-ion utama air laut pantai goa Cemara (mg/l) :

\begin{tabular}{|l|l|l|}
\hline No. & Jenis ion/metode uji & Goa Cemara, Bantul \\
\hline 1 & K/APHA 2005 sec 3500-K & 242 \\
\hline 2 & $\mathrm{Ca} /$ SNI 06-6989,13-2004 & 475,2 \\
\hline 3 & $\mathrm{Na} /$ APHA 2005 sec 3500-Na & 8506 \\
\hline 4 & $\mathrm{Mg} /$ SNI 06-6989,12-2004 & 1347,19 \\
\hline 5 & $\mathrm{Fe} /$ SNI 06-6989,4-2009 & $<0,023$ \\
\hline 6 & $\mathrm{Cl} /$ SNI 06-6989,19-2009 & 17922,4 \\
\hline 7 & SO4/ SNI 06-6989,20-2009 & 501 \\
\hline & Jumlah total & 28993,8 \\
\hline
\end{tabular}

Tabel 2. Komposisi air laut menurut Riley dan Skirrow :

\begin{tabular}{|l|l|l|}
\hline No. & Ion & $\mathrm{Gr} / \mathrm{kg}$ air laut \\
\hline 1 & $\mathrm{Cl}^{-}$ & 19,354 \\
\hline 2 & $\mathrm{Na}^{+}$ & 10,77 \\
\hline 3 & $\mathrm{~K}^{+}$ & 0,399 \\
\hline 4 & $\mathrm{Mg}^{2+}$ & 1,29 \\
\hline 5 & $\mathrm{Ca}^{2+}$ & 0,4121 \\
\hline 6 & $\mathrm{SO}^{2-}$ & 2,712 \\
\hline 7 & $\mathrm{Br}^{-}$ & 0,0637 \\
\hline 8 & $\mathrm{~F}^{-}$ & 0,0013 \\
\hline 9 & $\mathrm{~B}^{+}$ & 0,0045 \\
\hline 10 & $\mathrm{Sr}^{2+}$ & 0,0079 \\
\hline 11 & $\mathrm{IO}^{-}$ & $6,0.10^{-5}$ \\
\hline
\end{tabular}

Dari hasil pengamatan laju penguapan air laut rata-rata per hari adalah $0,5 \mathrm{~cm}$, pada kondisi cuaca yang cerah. Dari data ini maka dibuat skema tambak garam dengan kolam kedap air dengan satuan luas yang sama seperti pada gambar 3.
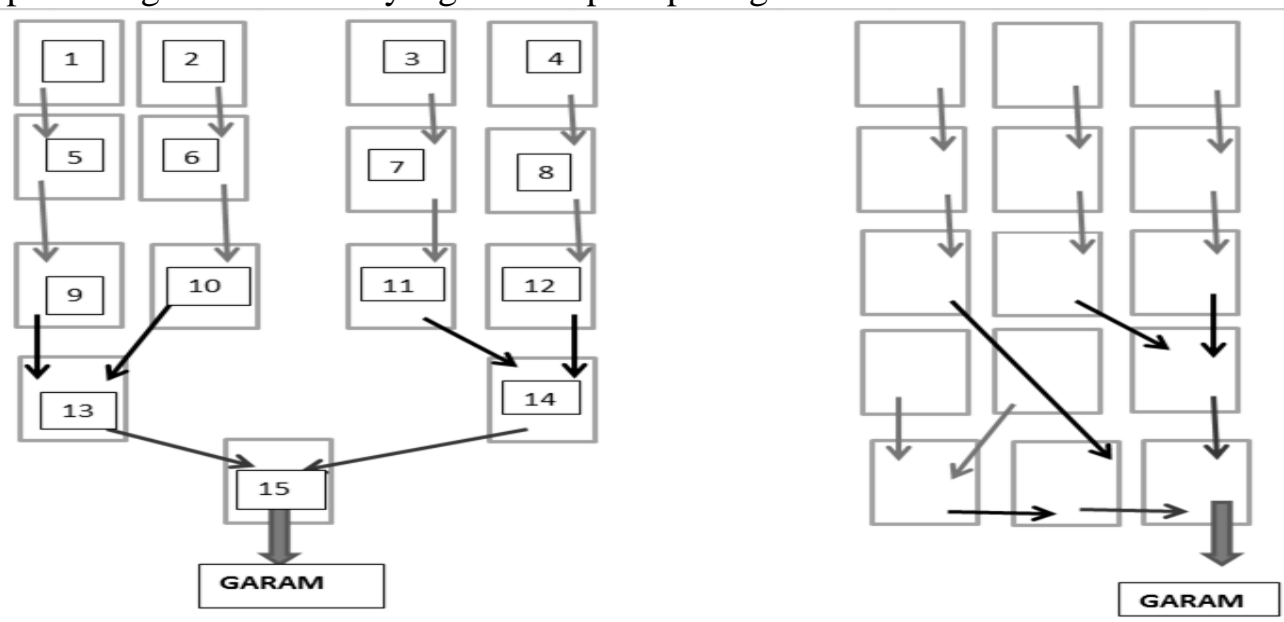

Gambar 3. Skema tambak garam dengan lantai terpal berukuran sama.

Dengan metoda ini waktu panen ketika sudah steady state dapat dipilih dari tabel yang ada di tabel 3. Semakin lama waktu panen, semakin besar ukuran kristal garam yang di dapat. Misal kita pilih waktu panen 2 hari, maka cara kerjanya sebagai berikut : 
1. hari ini (hari ke nol) tambak nomer 1,2,3,4,5,6,7 dan 8 diisi air laut setinggi $2 \mathrm{~cm}$.

2. Dua hari (hari ke 2) kemudian tambak no 1 dan 5 yang tingginya tinggal $1 \mathrm{~cm}$ dialirkan ke tambak no 9, sampai airnya tuntas, padatan yang tertinggal berupa lumpur, pasir, $\mathrm{Fe}_{2} \mathrm{O}_{3}$ dan padatan lain, dibiarkan dan nanti dibersihkan jika sudah terlihat banyak. Kemudian tambak no 1 dan 5 diisi lagi dengan air laut setinggi $2 \mathrm{~cm}$. Perlakuan yang sama untuk no. 2,6 ke 10, 3,7 ke 11 dan 4,8 ke 12.

3. Hari ke 4, tambak no. 9 dan 10 yang tingginya tinggal $1 \mathrm{~cm}$ dialirkan ke tambak no. 13, sampai airnya tuntas, padatan yang tertinggal berupa CaCO3 dibiarkan dan nanti dibersihkan jika sudah terlihat banyak. Perlakuan yang sama untuk tambak no. 11, 12 ke 14. Kemudian tambak no. 1 dan 5 yang tingginya tinggal $1 \mathrm{~cm}$ dialirkan ke tambak no. 9 sampai airnya tuntas. Selanjutnya tambak no 1 dan 5 diisi lagi dengan air laut setinggi $2 \mathrm{~cm}$. Perlakuan yang sama untuk no. 2,6 ke 10, 3,7 ke 11 dan 4,8 ke 12.

4. Hari ke 6, tambak no. 13 dan 14 yang tingginya tinggal $1 \mathrm{~cm}$ dialirkan ke tambak no. 15 , sampai airnya tuntas, padatan yang tertinggal berupa gipsum $\left(\mathrm{CaSO}_{4}\right)$ dibiarkan dan nanti dibersihkan jika sudah terlihat banyak. Kemudian tambak no. 9 dan 10 yang tingginya tinggal $1 \mathrm{~cm}$ dialirkan ke tambak no. 13 Perlakuan yang sama untuk tambak no. 11, 12 ke tambak no. 14. Kemudian tambak no. 1 dan 5 yang tingginya tinggal $1 \mathrm{~cm}$ dialirkan ke tambak no. 9 sampai airnya tuntas. Selanjutnya tambak no 1 dan 5 diisi lagi dengan air laut setinggi $2 \mathrm{~cm}$. Perlakuan yang sama untuk no. 2,6 ke 10, 3,7 ke 11 dan 4,8 ke 12.

5. Pada hari ke 8 garam di tambak no. 15 bisa dipanen berupa $\mathrm{CaSO} 4, \mathrm{NaCl}, \mathrm{MgSO} 4$, $\mathrm{MgCl}$, air yang tersisa berupa sari garam (CaSO4, MgSO4, $\mathrm{NaBr}, \mathrm{MgCl} 2$ ) bisa untuk penggumpal tahu atau dialirkan ke laut lagi. Prosedur lainnya sama dengan prosedur hari ke 6. Setelah ini garam dapat dipanen tiap 2 hari

Tabel 3. Waktu panen garam menggunakan kolam kedap air

\begin{tabular}{|c|c|c|c|}
\hline No. & $\begin{array}{l}\text { ketinggian cairan } \\
\text { awal }(\mathrm{cm})\end{array}$ & $\begin{array}{l}\text { ketinggian cairan } \\
\text { akhir }(\mathrm{cm})\end{array}$ & $\begin{array}{l}\text { waktu panen } \\
\text { (hari ) }\end{array}$ \\
\hline 1 & 1 & 0,5 & 1 \\
\hline 2 & 2 & 1 & 2 \\
\hline 3 & 3 & 1,5 & 3 \\
\hline 4 & 4 & 2 & 4 \\
\hline 5 & 5 & 2,5 & 5 \\
\hline 6 & 6 & 3 & 6 \\
\hline 7 & 7 & 3,5 & 7 \\
\hline 8 & 8 & 4 & 8 \\
\hline \multicolumn{4}{|c|}{ Dan seterusnya } \\
\hline 20 & 20 & 10 & 20 \\
\hline
\end{tabular}

Telah dicoba membuat garam dari air laut goa cemara dengan waktu tinggal 5 hari menggunakan ember dan berhasil sesuai perkiraan. Produk garam kotor hasil olahan kemudian dicuci dan dikeringkan dan di dapat hasil analisa seperti pada tabel 4.

Tabel 4. Hasil analisis garam dari air laut goa cemara

\begin{tabular}{|l|r|l|l|l|}
\hline keterangan & berat (mg) & \% berat & $\begin{array}{l}\text { Standar garam } \\
\text { industri }\end{array}$ & $\begin{array}{l}\text { Standar garam } \\
\text { konsumsi }\end{array}$ \\
\hline $\mathrm{NaCl}$ & 16554,05 & 98,93806558 & $>97,5 \%$ & $95 \%$ \\
\hline Sulfat & 83 & 0,496063467 & $<0,5 \%$ & $<2 \%$ \\
\hline Magnesium & 62,1 & 0,3711511 & $<0,3 \%$ & $<2 \%$ \\
\hline
\end{tabular}




\begin{tabular}{|l|r|l|l|l|} 
Kalsium & 18,58 & 0,111046497 & $<0,2 \%$ & $<2 \%$ \\
\hline Kalium & 14 & 0,083673356 & & \\
\hline
\end{tabular}

Dapat disimpulkan kualitas produk garam dari air laut pantai goa cemara sangat baik, diatas standar garam konsumsi bahkan sangat mendekati kualitas standar garam industri. Hanya kadar magnesium yang sedikit lebih tinggi dari standar garam industri, dapat diatasi dengan metoda pencucian garam yang lebih baik.

\section{KESIMPULAN DAN SARAN}

Hasil analisa densitas air laut dari pantai goa cemara sebesar 1,025 gr/cc dengan kandungan padartan 4,131 gr/100 gr air laut. Secara kuantitatif produksi garamnya $80 \%$ dari laut umumnya karena cukup dekat dengan muara, namun kualitas garam yang dihasilkan lebih bagus karena kandungan sulfat yang kecil. Laju penguapan air laut rata-rata per hari adalah 0,5 $\mathrm{cm}$, pada kondisi cuaca yang cerah. Metoda terpal menjanjikan masa panen garam yang fleksibel, dapat diaplikasikan dengan baik dan menghasilkan garam dengan kualitas yang baik. Kolam kedap air dapat berupa tanah yang diperkeras dengan batu kapur, terpal berwarna, beton berwarna, plastik, kayu, bambu dan lain-lain. Tentu saja harus dilakukan analisa keekonomisan dahulu.

\section{DAFTAR PUSTAKA}

[1] Ali Mahdi, 2007, upaya peningkatan produksi \& kualitas garam nasional, PT. Garam (Persero), Surabaya

[2] Dini Purbani, 2001, Proses Pembentukan Kristalisasi Garam, Pusat Riset Wilayah Laut dan Sumberdaya Nonhayati, Badan Riset Kelautan dan Perikanan Departemen Kelautan dan Perikanan

[3] Neville, H., M., 1963, The composition of Sea Water : Comparative and descriptive ocenography, Interscience Pub., New York New York.

[4] Riley, J. P., Skirrow G. 1975.,Chemical Oceanography, v. 4. 2nd ed. Academic Press, London, San Francisco. 